OPEN ACCESS

Edited by:

Zhanju Liu,

Tongji University, China

Reviewed by:

Faming Zhang,

Nanjing Medical University, China

Yinglei Miao,

Kunming Medical University, China

${ }^{*}$ Correspondence:

Jun Shen

shenjun79@sina.cn

Specialty section:

This article was submitted to

Gastrointestinal and

Hepatic Pharmacology,

a section of the journal

Frontiers in Pharmacology

Received: 20 June 2020

Accepted: 20 August 2020

Published: 18 September 2020

Citation:

Tan P, Li X, Shen J and Feng Q (2020) Fecal Microbiota Transplantation for the Treatment of Inflammatory Bowel

Disease: An Update.

Front. Pharmacol. 11:574533. doi: 10.3389/fphar.2020.574533

\section{Fecal Microbiota Transplantation for the Treatment of Inflammatory Bowel Disease: An Update}

\author{
Pufang $\operatorname{Tan}^{1}$, Xiaogang $L i^{1}$, Jun Shen ${ }^{1,2^{*}}$ and Qi Feng ${ }^{3}$ \\ 1 Division of Gastroenterology and Hepatology, Baoshan Branch, Renji Hospital, School of Medicine, Shanghai Jiao Tong \\ University, Shanghai, China, ${ }^{2}$ Division of Gastroenterology and Hepatology, Key Laboratory of Gastroenterology and \\ Hepatology, Ministry of Health, Inflammatory Bowel Disease Research Center, Renji Hospital, School of Medicine, Shanghai \\ Jiao Tong University, Shanghai Institute of Digestive Disease, Shanghai, China, ${ }^{3}$ Department of Radiology, Renji Hospital, \\ School of Medicine, Shanghai Jiao Tong University, Shanghai, China
}

Fecal microbiota transplantation (FMT) has successfully been applied for the treatment of recurrent Clostridioides difficile infection (CDI), which has led to studies on its application to other gastrointestinal diseases and extraintestinal diseases associated with gut microbiota dysbiosis. Recently, the results of FMT for patients with inflammatory bowel disease (IBD) have been encouraging. However, studies have not fully clarified the clinical application of this emerging therapy. Here, we aimed to review the current knowledge in this fast-growing field and characterize the effectiveness, safety and mechanisms of FMT for the treatment of IBD patients.

Keywords: fecal microbiota transplantation, inflammatory bowel disease, ulcerative colitis, Crohn's disease, microbiome

\section{INTRODUCTION}

Fecal microbiota transplantation (FMT) refers to the therapeutic procedure of transplanting fecal bacteria from healthy persons into patients (Gupta and Khanna, 2017). FMT is aimed at restoring the colonic microbiota through the introduction of fit bacterial population by infusing the gut microbiota, for example via colonoscopy, the orogastric tube, enema, or orally in the form of a capsule that contains the freeze-dried substance, to obtain an intestinal microbiota from a suitable donor. This therapeutic method has been proven to be incredibly successful for the treatment of recurrent Clostridioides difficile infection (CDI). (Drekonja et al., 2015)

The techniques of FMT deal with three key aspects, including donor selection, together with preparation of donor substance, and FMT delivery (Kelly et al., 2015; Mullish et al., 2018). Appropriate donors should include those of the age range of 18-60 years (Anand et al., 2017; Mullish et al., 2018), in addition to those with a BMI from 18 to $30 \mathrm{~kg} / \mathrm{m}^{2}$ (Alang and Kelly, 2015). The employment of multiple donors was more effective compared with single donor, because that multiple donors increase the microbial diversity in the fecal suspension compared with that of single donor (Levy and Allegretti, 2019). In each of the FMT preparations, the stool requires a weight of at least $25 \mathrm{~g}$ for lower gastrointestinal delivery and $12.5 \mathrm{~g}$ for upper gastrointestinal delivery (Cammarota et al., 2019). The final fecal substance preserved frozen at a temperature of $-80^{\circ} \mathrm{C}$ is considered to have a maximum shelf life of 2 years (Cammarota et al., 2019). Prior to utilisation, the frozen fecal material should be thawed at $37^{\circ} \mathrm{C}$, followed by use within a period of $6 \mathrm{~h}$ of thawing (Costello et al., 2015). The fecal microbiota 
could be supplied via the upper GI route (endoscopically or with the use of a nasogastric tube, nasoduodenal tube, or nasojejunal tube), the lower GI route (retention enema, colonoscopy), or through capsules (which contain either the freeze-dried or lyophilised fecal substance) (Mullish et al., 2018). Proton pump inhibitor and prokinetics (for example, metoclopramide) should be considered before FMT via the upper GI route (De Jager et al., 2012; Cohen et al., 2016). Bowel lavage must be performed before FMT via the lower GI route. Specifically, Polyethylene glycol preparations are preferred (Kelly et al., 2016). A single dose of loperamide (or other anti-exercise drugs) could be considered subsequent to the lower GI FMT delivery. Further, a minimum 24-h washing period is required from the last dose of antibiotics to FMT treatment (Cammarota et al., 2015). When recipients also show signs of long-term antibiotic use within 8 weeks after FMT, it is necessary to consult infectious disease experts or medical microbiologists for advice (Terveer et al., 2017).

FMT is considered approximately $90 \%$ success rate for individuals with recurrent or refractory CDI (Quraishi et al., 2017). In 2013, FMT was approved by the USA Food and Drug Administration for clinical applications of recurrent or refractory CDI (Surawicz et al., 2013). In addition to CDI, there are some studies that have proven that FMT could emerge as a productive method to treat inflammatory bowel disease (IBD). IBD refers to an intestinal disorder, including ulcerative colitis (UC) as well as Crohn's disease (CD). IBD is characterized by chronic inflammation of the gastrointestinal tract, as well as the periodicity of disease progression and remission. During disease activity, patients are likely to present with diarrhoea, coupled with nausea, loss of weight, anepithymia, fever, and celialgia (White et al., 2018). However, the precise pathophysiology is not entirely clear and the aetiology is multifactorial, influenced by individual genetic susceptibility, the external environment, internal gut microbiota, and the host immune response (Zhou et al., 2017). The imbalance of the gut microbiota has been suggested to markedly impact IBD progression (Zuo and Ng, 2018). Metabolomic and metagenomics research has identified the characteristics of IBD microbiota, in addition to finding a general decline in bacterial diversity, with a particular decline in members of Lachnospiraceae, as well as the Bacteroidetes phylum, coupled with an increase in Proteobacteria and Actinobacteria (Henson and Phalak, 2017). Biopsy samples attained from patients with CD were found a decline in Fecalibacterium prausnitzii which has the effects of anti-inflammatory (Sokol et al., 2008).

FMT is currently regarded as a productive intervention for recurring CDI (Bakken et al., 2011). Meanwhile, the use of FMT in IBD does not result in the same exceptional outcomes. However, emerging data have suggested the possibility that this therapy could have a better effect on these diseases. Reviewing the current evidence on the utility of FMT for the treatment of IBD, we focus on the effectiveness, safety and mechanisms of this new treatment, as well as ongoing research in this growing field.

\section{EFFICACY AND SAFETY OF FMT FOR IBD}

The traditional methodology of treating IBD was aimed at reducing the inflammatory. Nevertheless, the latest insights focus on the microbiome, in addition to the idea of dysbiosis and its latent role in IBD pathogenesis, resulting in irreplaceable therapeutic methodologies like FMT, a fascinating area of investigation. FMT was identified as a standard therapy for recurrent CDI, but its efficacy for IBD therapy is controversial (Basso et al., 2018). Most of the researches did not indicated key negative events or severe negative events that were considered medically associated with FMT treatment (Paramsothy et al., 2017b). Sood et al. (2020) performed a retrospective analysis of 101 active UC patients receiving multiple FMT via colonoscopy. The study found that the most common short-term adverse events of FMT included abdominal discomfort (30.8\%), flatulence $(15.9 \%)$, abdominal distension (9.8\%), borborygmi (7.9\%), and low-grade fever (7.6\%). The long-term adverse events were arthritis/arthralgia (6.5\%), urticaria (4.3\%), depression $(2.2 \%)$, allergic bronchitis $(2.2 \%)$, and partial sensorineural hearing loss $(2.2 \%)$. FMT appears to be a safe procedure.

\section{IBD With CDI}

Patients who get IBD are easily infected by $C$. difficile (Rodemann et al., 2007). Khoruts et al. (2016) suggested that FMT could be successful for clearing CDI form both IBD and non-IBD patients. Nevertheless, in patients with underlying IBD, the efficiency of single FMT therapy for this application was lower than that in patients without IBD (74.4\% vs. 92.1\%; $\mathrm{P}=0.0018)$. More than $1 / 4$ of patients with IBD (25.6\%) related to CDI experienced a significant flare of IBD after treatment with FMT. The latest study including $56 \mathrm{CDI}$ patients (22 UC and $13 \mathrm{CD}$ ) who received FMT procedures via colonoscopy was successful for $48 / 56(85.7 \%)$ of cases. In contrast, more than $50 \%$ of patients with UC experienced a sudden outbreak of IBD activity (Newman et al., 2017). The largest study of IBD patients with recurrent or refractory CDI included 67 patients $(35 \mathrm{CD}, 31 \mathrm{UC}$, and one indeterminate colitis). Respectively, the success rates of the first, second, and third fecal microbiota transplantation were 79\%, 88\%, and 90\%. After FMT, 25 patients (37\%) reported improvements in IBD disease activity, 20 patients (30\%) had no change, and for nine patients (13\%), disease worsened. Serious adverse events included CDI hospitalisation (2.9\%), hospitalisation for IBD flares $(2.9 \%)$, colectomy (1.4\%), small bowel obstruction (1.4\%), pancreatitis (1.4\%), and cytomegalovirus colitis $(1.4 \%)$ (Fischer et al., 2016). In conclusion, FMT has shown safety and efficacy in clearing CDI from patients with IBD, but the results need to be further evaluated systematically.

\section{Ulcerative Colitis}

To date, there have been five published randomised controlled trials (RCT) that assessed the effectiveness of FMT in UC (Table 1) (Moayyedi et al., 2015; Rossen et al., 2015; Paramsothy et al., 2017a; Costello et al., 2019; Sood et al., 2019). In July 2015, the first research using a nasoduodenal tube for FMT found that there is no statistically significant difference in the rate of endoscopic and clinical remission between FMT and control groups (Rossen et al., 2015). However, the other four trials using lower gastrointestinal microbiota transplantation showed encouraging results (Moayyedi et al., 2015; Paramsothy et al., 
TABLE 1 | Characteristics of randomized controlled trials on fecal microbiota transplantation (FMT) for ulcerative colitis.

\begin{tabular}{|c|c|c|c|c|c|c|c|c|c|c|c|}
\hline Study & $\begin{array}{l}\text { N (FMT/ } \\
\text { Control) }\end{array}$ & $\begin{array}{l}\text { Disease } \\
\text { activity }\end{array}$ & Control & Delivery & Frequency & Donor & Dosage & $\begin{array}{l}\text { Primary end- } \\
\text { point }\end{array}$ & $\begin{array}{c}\text { Follow } \\
\text { up }\end{array}$ & Remission & Response \\
\hline $\begin{array}{l}\text { Rossen et al., } \\
2015\end{array}$ & $\begin{array}{l}48(23 / \\
25)\end{array}$ & $\begin{array}{l}\text { SCCAI } \geq 4 \\
\text { and } \leq 11\end{array}$ & $\begin{array}{l}\text { Autologous } \\
\text { fecal } \\
\text { microbiota }\end{array}$ & Nasoduodenal & $\begin{array}{l}2 \text { (weeks } 0 \\
\text { and 3) }\end{array}$ & Single & $\begin{array}{l}\text { Minimum } 60 \\
\mathrm{~g} \\
\text { stool in } 500 \\
\mathrm{ml} \\
\text { saline }\end{array}$ & $\begin{array}{l}\text { SCCAl } \leq 2 \text { and } \\
\geq 1 \text { point } \\
\text { decrease in } \\
\text { Mayo } \\
\text { endoscopic } \\
\text { score }\end{array}$ & $\begin{array}{l}12 \\
\text { weeks }\end{array}$ & $\begin{array}{l}\text { FMT } \\
30.4 \%, \\
\text { control } \\
20 \%, p= \\
0.51\end{array}$ & $\begin{array}{l}\text { FMT } \\
47.8 \%, \\
\text { Control } \\
52 \%\end{array}$ \\
\hline $\begin{array}{l}\text { Moayyedi et al., } \\
2015\end{array}$ & $\begin{array}{l}75(38 / \\
37)\end{array}$ & $\begin{array}{l}\text { Mayo Clinic } \\
\text { score } \geq 4 \\
\text { with } \\
\text { endoscopic } \\
\text { score } \geq 1 \text {. }\end{array}$ & $\begin{array}{l}\text { Water } \\
\text { enema }\end{array}$ & Enema & 6 (weekly) & Single & $\begin{array}{l}50 \mathrm{~g} \text { stool in } \\
300 \mathrm{ml} \text { water }\end{array}$ & $\begin{array}{l}\text { Total Mayo } \\
\text { score } \leq 2 \text { with } \\
\text { endoscopic } \\
\text { score } 0 \text {. }\end{array}$ & $\begin{array}{l}7 \\
\text { weeks }\end{array}$ & $\begin{array}{l}\text { FMT 24\%, } \\
\text { control } 5 \%, \\
p=0.03^{\star}\end{array}$ & $\begin{array}{l}\text { FMT 39\%, } \\
\text { Control } \\
24 \%, p= \\
0.16\end{array}$ \\
\hline $\begin{array}{l}\text { Paramsothy } \\
\text { et al., } 2017 \text { a }\end{array}$ & $\begin{array}{l}81(41 / \\
40)\end{array}$ & $\begin{array}{l}\text { Mayo Clinic } \\
\text { score 4-10 } \\
\text { with } \\
\text { endoscopic } \\
\text { score } \geq 1 \text {. }\end{array}$ & $\begin{array}{l}\text { Saline } \\
\text { enema }\end{array}$ & $\begin{array}{l}\text { Initial } \\
\text { colonoscopy } \\
\text { then enema }\end{array}$ & $\begin{array}{l}40 \text { (5/week } \\
\text { for } 8 \text { weeks) }\end{array}$ & $\begin{array}{l}\text { Pooled } \\
\text { multi- } \\
\text { donor }\end{array}$ & $\begin{array}{l}37.5 \mathrm{~g} \text { stool } \\
\text { in } \\
150 \mathrm{ml}\end{array}$ & $\begin{array}{l}\text { Total Mayo } \\
\text { score } \leq 2 \text {, all } \\
\text { subscores } \leq 1 \text {, } \\
\text { and } \geq 1 \text { point } \\
\text { reduction in } \\
\text { endoscopic } \\
\text { score }\end{array}$ & $\begin{array}{l}8 \\
\text { weeks }\end{array}$ & $\begin{array}{l}\text { FMT } 27 \% \\
\text { control } 8 \% \\
p=0.02^{\star}\end{array}$ & $\begin{array}{l}\text { FMT54\%, } \\
\text { Control } \\
23 \%, p= \\
0.004^{*}\end{array}$ \\
\hline $\begin{array}{l}\text { Costello et al., } \\
2019\end{array}$ & $\begin{array}{l}73(38 / \\
35)\end{array}$ & $\begin{array}{l}\text { Mayo Clinic } \\
\text { score } 310 \\
\text { with } \\
\text { endoscopic } \\
\text { score } \geq 2 \text {. }\end{array}$ & $\begin{array}{l}\text { Autologous } \\
\text { fecal } \\
\text { microbiota }\end{array}$ & $\begin{array}{l}\text { Initial } \\
\text { colonoscopy } \\
\text { then enema }\end{array}$ & $\begin{array}{l}3 \text { (week } 0 \\
\text { colonoscop- } \\
\text { y, } 2 \text { enemas } \\
\text { week 1) }\end{array}$ & $\begin{array}{l}\text { Pooled } \\
\text { multi- } \\
\text { donor }\end{array}$ & $\begin{array}{l}\text { Colonoscopy } \\
50 \mathrm{~g} \text { stool in } \\
200 \mathrm{ml} \\
\text { saline } \\
\text { and glycerol, } \\
\text { enema } 25 \mathrm{~g} \\
\text { stool in } 100 \\
\mathrm{ml}\end{array}$ & $\begin{array}{l}\text { Total Mayo } \\
\text { score } \leq 2 \text { and } \\
\text { endoscopic } \\
\text { score } \leq 1\end{array}$ & $\begin{array}{l}8 \\
\text { weeks }\end{array}$ & $\begin{array}{l}\text { FMT } 32 \%, \\
\text { Contro I } \\
9 \%, p= \\
0.02^{*}\end{array}$ & $\begin{array}{l}\text { FMT 55\%, } \\
\text { Control } \\
20 \%, p \leq \\
0.01^{\star}\end{array}$ \\
\hline Sood et al., 2019 & $\begin{array}{l}61(31 / \\
30)\end{array}$ & $\begin{array}{l}\text { Mayo score } \\
\leq 2 \\
\text { with each } \\
\text { subscore } \leq \\
1\end{array}$ & NR & colonoscopic & $\begin{array}{l}7 \text { (Weeks } 0 \text {, } \\
8,16,24, \\
32,40, \text { and } \\
48)\end{array}$ & $\begin{array}{l}\text { Single } \\
\text { and } \\
\text { unrelated }\end{array}$ & $\begin{array}{l}100 \mathrm{~g} \text { in } 200 \\
\mathrm{ml}\end{array}$ & $\begin{array}{l}\text { Mayo score } \leq \\
2, \text { all } \\
\text { subscores } \leq 1\end{array}$ & $\begin{array}{l}48 \\
\text { weeks }\end{array}$ & $\begin{array}{l}\text { FMT } \\
87.1 \%, \\
\text { control } \\
6.7 \%, p= \\
0.11\end{array}$ & $N R$ \\
\hline
\end{tabular}

SSCAI, simple clinical colitis activity index. *Statistically significant.

2017a; Costello et al., 2019; Sood et al., 2019). Moayyedi et al. (2015) found that patients with UC for less than 1 year, but not longer, could enter a state of remission after treatment with FMT. These different findings are likely due to dissimilarities in the routes of administration, in addition to the stool donors and dosing schedules. Sood et al. (2019) conducted a study among 61 UC patients in clinical remission. Participants were randomly assigned to receive either FMT or placebo. Maintaining clinical remission at 48 weeks was achieved in $87.1 \%$ patients receiving FMT compared with $66.7 \%$ receiving placebo. There was a statistically significant impact of FMT on Endoscopic remission (FMT: $58.1 \%$ compared with placebo: $26.7 \%, \mathrm{p}=$ 0.026) and histological remission (FMT: $45.2 \%$ compared with placebo: $16.7 \%, p=0.033$ ). It is indicated that maintenance FMT in UC patients with clinical remission could help sustain endoscopic, histological, and clinical remission.

One recently published meta-analysis assessing the aforementioned four RCTs indicated that 39 of 140 (28\%) patients achieved clinical remission in the FMT groups compared to 13 of 137 (9\%) patients in the placebo groups, with an odds ratio of 3.67 (95\% CI: $1.82-7.39, \mathrm{P}<0.01)$. Compared to 38 of 137 (28\%) placebo patients, 69 of 140 (49\%) patients in FMT groups achieved clinical responses, and the odds ratio was 2.48 (95\% CI: 1.18-5.21, $\mathrm{P}=0.02$ ) (Costello et al., 2017). The latest systematic review and meta-analysis considered 27 research papers, which included 596 adult and paediatric IBD patients, and 459 patients were treated with FMT. During the follow-up period, 132 of 459 (28.8\%) patients achieved clinical remission. The clinical effective rate was 53\% (241/ 459). The overall clinical remission rate for UC was $21 \%$ (95\% CI: 8$37 \%)$. As subgroup analyses revealed, the clinical remission rate prevailing in adult UC patients amounted to $26 \%$ (95\% CI: $10 \%-$ $48 \%$ ), whereas paediatric patients showed a rate of $10 \%$ (95\% CI: 0\%-43\%) (Fang et al., 2018). Hence, the therapeutic effect of FMT for patients with UC is very promising, particularly for patients with multiple transfusions through the lower digestive tract.

\section{Crohn's Disease}

The evidence on the effect of FMT in CD has recently been presented. There are currently several active trials studying the effectiveness of FMT for CD, and the results are diverse (Table 2) (Cui et al., 2015; Suskind et al., 2015; Wei et al., 2015; Vaughn et al., 2016; Vermeire et al., 2016; Goyal et al., 2018; Gutin et al., 2019; Sokol et al., 2020; Xiang et al., 2020). Xiang et al. (2020) studied $174 \mathrm{CD}$ patients treated with FMT via Mid-gut including nasojejunal tube, endoscopy and mid-gut TET (except one through colonic TET). At 1 month after FMT, 76\% (19/25), $72.7 \%$ (101/139), 70.6\% (12/17) and 61.6\% (90/146) of patients achieved improvement in hematochezia, abdominal pain, fever and diarrhoea respectively. At the final follow-up, the clinical remission was achieved in $20.1 \%(35 / 174)$ and the clinical 
TABLE 2 | Characteristics of fecal microbiota transplantation for Crohn's disease.

\begin{tabular}{|c|c|c|c|c|c|c|c|c|c|c|c|}
\hline Study & $\mathbf{N}$ & Age (y) & $\begin{array}{l}\text { Disease } \\
\text { Activity }\end{array}$ & Delivery & Frequency & Donor & Dosage & $\begin{array}{l}\text { Primary end- } \\
\text { point }\end{array}$ & $\begin{array}{c}\text { Follow } \\
\text { up }\end{array}$ & Remission & Response \\
\hline $\begin{array}{l}\text { Vaughn et al., } \\
2016\end{array}$ & 19 & $>18$ & $\mathrm{HBI} \geq 5$ & Colonoscopy & 1 & Unrelated & $\begin{array}{l}50 \mathrm{~g} \\
\text { stool } \\
\text { in } \\
250 \mathrm{ml} \\
\text { solution }\end{array}$ & $\begin{array}{l}\mathrm{HBI}<5 \text { at } \\
4 \text { weeks }\end{array}$ & $\begin{array}{l}26 \\
\text { weeks }\end{array}$ & $53 \%$ & $58 \%$ \\
\hline $\begin{array}{l}\text { Vermeire et al., } \\
2016\end{array}$ & 6 & $28-53$ & $\begin{array}{l}\text { Widespread } \\
\text { involvement of } \\
\text { the colon and/ } \\
\text { or ileum. }\end{array}$ & $\begin{array}{l}\text { Nasojejunal or rectal } \\
\text { tube }\end{array}$ & $\begin{array}{l}2 \text { (daily for } \\
\text { consecutive } \\
\text { days) }\end{array}$ & $\begin{array}{l}\text { Patient- } \\
\text { directed } \\
\text { donor }\end{array}$ & $\begin{array}{l}200 \mathrm{~g} \\
\text { stool in } \\
400 \mathrm{ml} \\
\text { saline }\end{array}$ & SES-CD $<3$ & $\begin{array}{l}8 \\
\text { weeks }\end{array}$ & $0 \%$ & $0 \%$ \\
\hline Cui et al., 2015 & 30 & $15-71$ & $\mathrm{HBI} \geq 7$ & $\begin{array}{l}\text { Duodenum via } \\
\text { gastroscope }\end{array}$ & 1 & $\begin{array}{l}\text { Patient- } \\
\text { directed } \\
\text { donor }\end{array}$ & $\begin{array}{l}150- \\
200 \mathrm{ml}\end{array}$ & $\mathrm{HBI} \leq 4$ & $\begin{array}{l}15 \\
\text { months }\end{array}$ & $76.7 \%$ & $86.7 \%$ \\
\hline Wei et al., 2015 & 3 & $16-70$ & $\begin{array}{l}\text { CDAl 150-400 } \\
\text { and CRP > } 10 \\
\mathrm{mg} / \mathrm{L}\end{array}$ & $\begin{array}{l}\text { Nasojejunal or } \\
\text { colonoscopy }\end{array}$ & 1 & Unrelated & $\begin{array}{l}60 \mathrm{~g} \\
\text { stool } \\
\text { in } 350 \\
\mathrm{ml} \\
\text { saline }\end{array}$ & $\begin{array}{l}\mathrm{CDAl}<150 \\
\text { and } \mathrm{CRP}<10 \\
\mathrm{mg} / \mathrm{l}\end{array}$ & $\begin{array}{l}4 \\
\text { weeks }\end{array}$ & $0 \%$ & NR \\
\hline $\begin{array}{l}\text { Goyal et al., } \\
2018\end{array}$ & 4 & $2-22$ & $\begin{array}{l}\text { PCDAl } 10-40 \\
\text { or lactoferrin/ } \\
\text { calprotectin } \\
2 \times \text { upper limit of } \\
\text { normal }\end{array}$ & $\begin{array}{l}\text { Distal duodenum or } \\
\text { jejunum via } \\
\text { gastroscopy or } \\
\text { colonoscopy }\end{array}$ & 1 & $\begin{array}{l}\text { Patient- } \\
\text { directed } \\
\text { donor }\end{array}$ & $\begin{array}{l}150 \mathrm{~g} \\
\text { stool in } \\
250- \\
300 \mathrm{ml} \\
\text { saline }\end{array}$ & $\begin{array}{l}\text { PDAl }<10 \text { or } \\
\text { normalization of } \\
\text { lactoferrin/ } \\
\text { calprotectin at } \\
1 \text { month }\end{array}$ & $\begin{array}{l}6 \\
\text { months }\end{array}$ & $50 \%$ & $75 \%$ \\
\hline $\begin{array}{l}\text { Suskind et al., } \\
2015\end{array}$ & 9 & $12-19$ & $\begin{array}{l}\text { PCDAl } \\
10-29\end{array}$ & Nasogastric tube & 1 & Related & $\begin{array}{l}30 \mathrm{~g} \\
\text { stool } \\
\text { in } 100- \\
200 \mathrm{ml} \\
\text { saline }\end{array}$ & PCDAl $<10$ & $\begin{array}{l}12 \\
\text { weeks }\end{array}$ & $\begin{array}{l}78 \% \text { at } 2 \\
\text { weeks, } 56 \% \\
\text { at } 6 \text { and } 12 \\
\text { weeks }\end{array}$ & NR \\
\hline Gutin et al., 2019 & 10 & $18-70$ & $\mathrm{HBI} \geq 3$ & Colonoscopy & 1 & $\begin{array}{l}\text { Unrelated } \\
\text { donors }\end{array}$ & $N R$ & $\begin{array}{l}\text { decrease in } \\
\mathrm{HBI} \geq 3 \text { at } 1 \\
\text { month }\end{array}$ & $\begin{array}{l}12 \\
\text { months }\end{array}$ & $10 \%$ & $30 \%$ \\
\hline Xiang et al., 2020 & 174 & $\begin{array}{l}\text { Median } \\
\text { was } 33 \\
\text { (IQR: } \\
\text { 23-43) }\end{array}$ & $\begin{array}{l}\text { The median of } \\
\text { HBI was } 8 \\
\text { (IQR: 6-10) }\end{array}$ & $\begin{array}{l}\text { Mid-gut includ } \\
\text { ing endoscopy, } \\
\text { nasojejunal tube, and } \\
\text { mid-gut TET (except } \\
\text { one through colonic } \\
\text { TET) }\end{array}$ & $\begin{array}{l}\text { Median was } \\
3.5 \text { (IQR: 2- } \\
5)\end{array}$ & $\begin{array}{l}\text { Related } \\
\text { and } \\
\text { unrelated } \\
\text { donors }\end{array}$ & NR & $\begin{array}{l}\text { The rate of } \\
\text { improvement in } \\
\text { each } \\
\text { therapeutic } \\
\text { target }\end{array}$ & $\begin{array}{l}\text { Median } \\
\text { was } \\
43 \\
\text { months } \\
\text { (IQR: } \\
\text { 28-59) }\end{array}$ & $20.1 \%$ & $43.7 \%$ \\
\hline Sokol et al., 2020 & 17 & $18-70$ & $\mathrm{HBI}>4$ & Colonoscopy & 1 & $\begin{array}{l}\text { Unrelated } \\
\text { donor }\end{array}$ & $\begin{array}{l}50- \\
100 g\end{array}$ & $\begin{array}{l}\text { successful } \\
\text { colonization of } \\
\text { donor } \\
\text { microbiota }\end{array}$ & $\begin{array}{l}24 \\
\text { weeks }\end{array}$ & $\begin{array}{l}\text { FMT group: } \\
87.5 \% \text { at } 10 \\
\text { weeks; } \\
\text { control group } \\
44.4 \%\end{array}$ & NR \\
\hline
\end{tabular}

HBI, Harwey Bradshaw Index; CDAl, Crohn's Disease Activity Index; PCDAl, Pediatric Crohn's Disease Activity Index; TET, transendoscopic enteral tubing; IQR, interquartile range; NR, not recorded.

response was achieved in $43.7 \%$ (76/174). Sokol and colleagues conducted a randomized controlled study of FMT in CD patients. Participants were randomly assigned either to the FMT group or the control group. The incidence of flare in the FMT group was lower than in the control group but there was not a statistically significant impact of FMT on clinical remission. The clinical remission at 10 and 24 weeks was $7 / 8(87.5 \%)$ and $4 /$ $8(50.0 \%)$ in the FMT group and $4 / 9(44.4 \%)$ and $3 / 9(33.3 \%)$ in the control group. Crohn's Disease Endoscopic Index of Severity decreased at 6 weeks in the FMT group $(p=0.03)$ but not in the control group ( $\mathrm{p}=0.8)$. On the contrary, the CRP level increased at 6 weeks in the control group $(\mathrm{p}=0.008)$ but not in the FMT group ( $\mathrm{p}=0.5)$ (Sokol et al., 2020).

Xiang et al. (2020) believed that FMT in CD against targeted therapeutics was efficient, especially hematochezia, abdominal pain, diarrhoea and fever. Whereas, Further research needs to be conduced to gain more high-quality data and provide conclusions with respect to the use of FMT for these patients and subsequently which $\mathrm{CD}$ phenotypes are most likely to benefit.

\section{Pouchitis}

Pouchitis is the most common complication of patients with refractory UC with ileal pouch-anal anastomosis, and morbidity can reach nearly $50 \%$. Similar to that with UC and CD, a decrease in intestinal microbial diversity plays a critical role in its pathogenesis. Antibiotics might induce remission of pouchitis but can lead to recurrence (Shen, 2012; Maharshak et al., 2017). Probiotics can prevent recurrence, which might be related to recovery of the mucosal barrier (Persborn et al., 2013). Five studies have been conducted to evaluate FMT in patient with pouchitis (Table 3) (Landy et al., 2015; Stallmach et al., 2016; 
TABLE 3 | Characteristics of fecal microbiota transplantation for pouchitis.

\begin{tabular}{|c|c|c|c|c|c|c|c|c|c|c|c|}
\hline Study & $\mathbf{N}$ & $\begin{array}{l}\text { Age } \\
\text { (y) }\end{array}$ & Disease Activity & Delivery & Frequency & Donor & Dosage & $\begin{array}{c}\text { Primary end- } \\
\text { point }\end{array}$ & $\begin{array}{c}\text { Follow } \\
\text { up }\end{array}$ & Remission & Response \\
\hline $\begin{array}{l}\text { Landy et al., } \\
2015\end{array}$ & 8 & $\begin{array}{c}24- \\
63\end{array}$ & $\begin{array}{l}\text { Chronic antibiotic } \\
\text { refractory } \\
\text { Pouchetis,PDAl } \geq 7\end{array}$ & Nasogastric & 1 & NR & $\begin{array}{l}18 \mathrm{~g} \\
\text { stool/ } \\
30 \mathrm{ml} \\
\text { saline } \\
\text { solution) }\end{array}$ & $\mathrm{PDAl} \leq 4$ & $\begin{array}{l}4 \\
\text { weeks }\end{array}$ & $0 \%$ & $25 \%$ \\
\hline $\begin{array}{l}\text { Nishida et al., } \\
2019\end{array}$ & 3 & $\begin{array}{c}24- \\
52\end{array}$ & $\mathrm{PDAl} \geq 7$ & Colonoscopy & 1 & Related & $N R$ & $\begin{array}{l}\text { Reduction in } \\
\text { total PDAI } \geq 3 \\
\text { at } 8 \text { weeks }\end{array}$ & $\begin{array}{l}8 \\
\text { weeks }\end{array}$ & $0 \%$ & $33 \%$ \\
\hline $\begin{array}{l}\text { Stallmach et al., } \\
2016\end{array}$ & 5 & $\begin{array}{c}26- \\
40\end{array}$ & $\begin{array}{l}\text { Chronic antibiotic } \\
\text { refractory pouchitis, } \\
\text { PDAl 9-14 }\end{array}$ & $\begin{array}{l}\text { Jejunum via upper } \\
\text { gastrointestinal tract } \\
\text { endoscopy }\end{array}$ & $\begin{array}{l}1-7(3-4 \\
\text { weeks } \\
\text { intervals) }\end{array}$ & $\begin{array}{l}\text { Two } \\
\text { unrelated }\end{array}$ & $\begin{array}{l}75 \mathrm{~g} \text { stool } \\
\text { in } 200 \mathrm{ml} \\
\text { saline }\end{array}$ & $\mathrm{NR}$ & $\begin{array}{l}3 \\
\text { months }\end{array}$ & $\begin{array}{l}80 \% \text { at } 4 \\
\text { weeks, } 60 \% \\
\text { at } 3 \text { months }\end{array}$ & $100 \%$ \\
\hline $\begin{array}{l}\text { Herfarth et al., } \\
2019\end{array}$ & 6 & $\begin{array}{c}22- \\
60\end{array}$ & $\begin{array}{l}\text { Chronic antibiotic } \\
\text { refractory pouchi- } \\
\text { tis (mPDAl } \geq 5 \\
\text { and a history } \\
\text { of } \geq 4 \text { antibiotic } \\
\text { therapies for } \\
\text { pouchitis in the } \\
\text { last } 12 \text { months) }\end{array}$ & $\begin{array}{l}\text { Endoscopic } \\
\text { (eFMT) } \\
\text { and oral } \\
\text { encapsulated } \\
\text { (oFMT) }\end{array}$ & $\begin{array}{l}\text { eFMT: } 2 ; \\
\text { oFMT: } \\
\text { daily for } \\
14 \text { days }\end{array}$ & Unrelated & $\begin{array}{l}\text { eFMT: } \\
12 \mathrm{~g} \text { stool } \\
\text { in } 30 \mathrm{ml} \\
\text { oFMT: } \\
4.2 \mathrm{~g} \text { stool }\end{array}$ & $\begin{array}{l}\text { The safety of } \\
\text { the combined } \\
\text { eFMT } \\
\text { and oFMT }\end{array}$ & $\begin{array}{l}16 \\
\text { weeks }\end{array}$ & $17 \%$ & $17 \%$ \\
\hline $\begin{array}{l}\text { Selvig et al., } \\
2020\end{array}$ & 19 & $\begin{array}{l}18- \\
74\end{array}$ & $\begin{array}{l}\text { Chronic pouchitis } \\
\text { (pouch symptoms } \\
>4 \text { weeks and } \\
\text { endoscopic } \\
\text { evaluation con- } \\
\text { frming infamma- } \\
\text { tion of the pouch }\end{array}$ & Pouchoscopy & $1-2$ & $\begin{array}{l}12 \\
\text { months }\end{array}$ & $\begin{array}{l}250 \mathrm{ml} \\
\text { donor } \\
\text { fecal } \\
\text { suspen- } \\
\text { sion ( } 25 \mathrm{~g} \\
\text { stool) }\end{array}$ & $\begin{array}{l}\text { Clinical } \\
\text { improvement at } \\
\text { week } 4 \text {. }\end{array}$ & $\begin{array}{l}12 \\
\text { months }\end{array}$ & 0 & $\begin{array}{l}9 \% \\
\text { (among } \\
\text { patients } \\
\text { receiving } \\
\text { double } \\
\text { FMT) }\end{array}$ \\
\hline
\end{tabular}

PDAl, Pouchitis Disease Activity Index; FMT, fecal microbiota transplantation; eFMT, endoscopic FMT; oFMT, oral encapsulated FMT.

Herfarth et al., 2019; Nishida et al., 2019; Selvig et al., 2020). In the four studies using a single-source fecal bacteria, none of the patients achieved remission of clinical symptoms (Landy et al., 2015; Herfarth et al., 2019; Nishida et al., 2019; Selvig et al., 2020). Stallmach et al. (2016) used multi-source fecal bacteria and many transplantations, and $80 \%$ of the patients achieved clinical remission, with the rest attaining a clinical response. It was lacked of available data and randomized controlled trials to demostrate the efficiency of FMT in treating Pouchitis. Recently, A prospective randomized controlled trial assessing the efficacy of FMT in pouchitis patients was prematurely stopped for low donor FMT engraftment (Selvig et al., 2020). Larger randomized controlled trials are needed to validate the effectiveness of FMT in pouchitis.

\section{IMMUNOMODULATORY EFFECTS AND MECHANISMS OF FMT}

FMT therapy has been used for CDI for decades, whereas its use for IBD began since the year 2012. Reviewed from current researches, the immunomodulatory effects and mechanisms of FMT have been concluded:

\section{Intestinal Microbial Ecology}

Various gastrointestinal disorders, which include IBD, are linked to changes in the intestinal microbiota composition and metabolic dysbiosis. It is not known if tissue impairment is caused by abnormal immune responses to normal microbiota or by a normal immune response to abnormal microbiota or if dysbiosis constitutes a cause or outcome of IBD (Sheehan et al., 2015; Ni et al., 2017). FMT is considered a promising therapeutic methodology for IBD patients, primarily to achieve outcomes of intestinal microbial restoration (Burrello et al., 2019).

FMT can increase the diversity of intestinal microorganisms, together with rebuilding the immune system and maintaining the balance of intestinal microecology. Even though comprehensive studies on increasing the microbial diversity of the intestines are continually being updated, many current studies could provide such proof-of-concept. Zeng et al. (2019) carried out a study analyzing the latest trials dealing with the immunomodulatory effects and underlying processes of probiotics and FMT, in addition to examining the effectiveness and safety of probiotics and FMT for medical experiments. Their group concluded that the intestinal microbiota from the donors limited intestinal permeability, inhibited intestinal epithelial cell apoptosis, re-established the function of the intestinal barrier, mitigated the production of proinflammatory cytokines and restored the metabolism of secondary bile acids in the intestinal tract. Further, FMT could compete with or antagonise pathogenic bacteria, in addition to enhancing insulin resistance. As a result, the patient's immunity is improved. The IBD microbiome was discovered to promote inflammation and show signs of augmented oxidative stress, in addition to the enhanced secretion of type II toxins and the elevated level of virulence-associated bacterial genes (Erickson et al., 2012). 


\section{T-Cell Populations}

The populations of gut-linked immune cells make a critical contribution to initiating and sustaining intestinal inflammation, which occurs in patients with IBD and in experimental models of intestinal inflammation (Blumberg et al., 1999; Kaser et al., 2010). Natividad et al. (2015) showed that mice colonized with microbial populations from UC patients that were low in Firmicutes were more sensitive to colitis than mice colonized with Firmicutes-rich faeces or synthetic ecosystems. Here, Firmicutes bacteria were not abundant, the expression of Th17-related genes was increased, and the $\mathrm{CD}^{4+}$ cells expressing IL-17A were expanded. Further, bacterial isolates supplemented with Firmicutes can eliminate the enhanced Th17 response in vitro, and the results support the use of ecotherapy strategies rich in Firmicutes to prevent or treat UC.

Populations of T cells that are separated from the colons of mice treated by FMT exhibit a decrease in their ability to proliferate compared to those isolated from colitis mice without FMT treatment. Phenotypically, FMT-treated mice show lower percentages of $\mathrm{CD}^{8+} \mathrm{T}$ and $\mathrm{CD}^{4+} \mathrm{T}$ cells, which express the cytotoxicity-related molecule CD107a. This further supports the observation of a decrease in the pro-inflammatory phenotype of colonic T cells in mice treated with FMT (Burrello et al., 2019).

\section{Inflammatory Cytokines}

UC has been linked to abnormal Th2 cell response-mediated inflammation (Oh et al., 2017). Burrello and colleges induced intestinal inflammation in mice using the chronic infusion of dextran sodium sulphate (DSS), which is similar to that observed in patients with IBD. Both the mucus and faeces from normal biological donors were given orally to the mice with established chronic colitis induced by DSS. Normoxic FMT therapy was found to lower the intestinal inflammation, as suggested by a robust decline in not only the colonic expression of the proinflammatory marker interferon (IFN)- $\gamma$ but also tumor necrosis factor (TNF), interleukin (IL)-1 $\beta$, IL-17, and IL-6. Restoring a main ecology of normal organisms contributed to resolving inflammation (Burrello et al., 2019). Wei et al. (2018) identified that FMT could alleviate the acute colitis stimulated by DSS in mice and FMT results in the upregulation of not only aryl hydrocarbon receptor (AHR) but also transforming growth factor beta (TGF- $\beta$ ) and IL-10 in colon tissues. Wang et al. (2020) carried out a study on active UC patients who received three times FMT from a single donor at an interval of 23 months. The clinical response was achieved in 14/16 (87.5\%) patients. Compared to those before FMT, serum levels of IL-6, IL-1Ra, epithelial neutrophil activating peptide (ENA)78 , and interferon-inducible protein (IP)-10 significantly decreased after the second FMT $(\mathrm{P}<0.05)$, and serum levels of vascular cell adhesion molecule (VCAM)-1, granulocyte-colony stimulating factor (G-CSF) and mucosae-associated epithelial chemokine (MEC) significantly decreased after both the first and second FMT $(\mathrm{P}<0.05)$. Those findings shed light on the fact that FMT has the potential to control IBD through augmenting anti-inflammation cytokines and reducing proinflammatory cytokines.

\section{CONCLUSION AND FUTURE PERSPECTIVES}

The understanding of FMT effectiveness for IBD is in its infancy even today. The preliminary findings from medical experiments are conflicting, perhaps owing to the dissimilarities existing in patient populations among various research works, disease seriousness in participants, the delivery processes of FMT, FMT preparations, and the follow-up after transplantation (Rubin, 2015). Nevertheless, the latent potential of FMT for the treatment of IBD should be addressed. It is not clear why some patients with IBD respond impressively following FMT, whereas other patients fail to respond. Nonetheless, it is evident that FMT does not refer to a "one size fits all" and many determinants seem to contribute to its successful use for the treatment of IBD. The host genotype, the course of disease, the use of antibiotics linked to illness onset, the specific types of IBDlinked dysbiosis, and/or donor attributes are all determinants that can potentially dictate the ultimate result. Accordingly, further investigations and a better understanding of this application are required (Rossen et al., 2015). To conclude, applying FMT to manage IBD is likely to constitute an intriguing treatment choice; nonetheless, large and methodical studies are lacking. Further, many concerns related to pathophysiological, methodological, and mechanistic factors require an explanation.

FMT refers to a new potential option for treating IBD; nonetheless, there are many issues that still exist. More research is required to build a more comprehensive and deeper knowledge base, with respect to the entire treatment process ranging from FMT methodologies to FMT immunomodulatory impacts and mechanisms. Being a new treatment for IBD, its efficacy and safety are still not certain, and patient acceptability is also not high; accordingly, longer-term follow-up investigations are required. Standards regarding donor selection are also required. Through further studies, better methodologies and more effective protocols to prepare fecal substances and administer FMT will be realized. Moreover, related laws and regulations need to be formulated to standardise and limit all aspects of the treatment.

\section{AUTHOR CONTRIBUTIONS}

PT and XL collected the papers and data, analyzed the conclusions, drafted the manuscript. JS and QF presented the idea of this paper, supported the funding, analyzed the conclusions, drafted, and revised the manuscript.

\section{FUNDING}

Supported by grants from National Natural Science Foundation of China (No. 81770545 \& 81701746) and MDT Project of Clinical Research Innovation Foundation, Renji Hospital, School of Medicine, Shanghai Jiaotong University (PYI-17003), and North Shanghai Medical Star Talent Training Program of Baoshan Branch Renji Hospital (rbxxrc-2019-008). 


\section{REFERENCES}

Alang, N., and Kelly, C. R. (2015). Weight gain after fecal microbiota transplantation. Open Forum Infect. Dis. 2, ofv004. doi: 10.1093/ofid/ofv004

Anand, R., Song, Y., Garg, S., Girotra, M., Sinha, A., Sivaraman, A., et al. (2017). Effect of Aging on the Composition of Fecal Microbiota in Donors for FMT and Its Impact on Clinical Outcomes. Dig. Dis. Sci. 62, 1002-1008. doi: 10.1007/s10620-017-4449-6

Bakken, J. S., Borody, T., Brandt, L. J., Brill, J. V., Demarco, D. C., Franzos, M. A., et al. (2011). Treating Clostridium difficile infection with fecal microbiota transplantation. Clin. Gastroenterol. Hepatol. 9, 1044-1049. doi: 10.1016/ j.cgh.2011.08.014

Basso, P. J., Camara, N. O. S., and Sales-Campos, H. (2018). Microbial-Based Therapies in the Treatment of Inflammatory Bowel Disease - An Overview of Human Studies. Front. Pharmacol. 9:1571. doi: 10.3389/fphar.2018.01571

Blumberg, R. S., Saubermann, L. J., and Strober, W. (1999). Animal models of mucosal inflammation and their relation to human inflammatory bowel disease. Curr. Opin. Immunol. 11, 648-656. doi: 10.1016/S0952-7915(99) 00032-1

Burrello, C., Giuffrè, M. R., Macandog, A. D., Diaz-Basabe, A., Cribiù, F. M., Lopez, G., et al. (2019). Fecal Microbiota Transplantation Controls Murine Chronic Intestinal Inflammation by Modulating Immune Cell Functions and Gut Microbiota Composition. Cells 8, 517. doi: 10.3390/cells8060517

Cammarota, G., Masucci, L., Ianiro, G., Bibbò, S., Dinoi, G., Costamagna, G., et al. (2015). Randomised clinical trial: fecal microbiota transplantation by colonoscopy vs. vancomycin for the treatment of recurrent Clostridium difficile infection. Aliment Pharmacol. Ther. 41, 835-843. doi: 10.1111/ apt.13144

Cammarota, G., Ianiro, G., Kelly, C. R., Mullish, B. H., Allegretti, J. R., Kassam, Z., et al. (2019). International consensus conference on stool banking for fecal microbiota transplantation in clinical practice. Gut 68, 2111-2121. doi: 10.1136/gutjnl-2019-319548

Cohen, N. A., Livovsky, D. M., Yaakobovitch, S., Ben Yehoyada, M., Ben Ami, R., Adler, A., et al. (2016). A Retrospective Comparison of Fecal Microbial Transplantation Methods for Recurrent Clostridium Difficile Infection. Isr. Med. Assoc. J. 18, 594-599.

Costello, S. P., Conlon, M. A., Vuaran, M. S., Roberts-Thomson, I. C., and Andrews, J. M. (2015). Fecal microbiota transplant for recurrent Clostridium difficile infection using long-term frozen stool is effective: clinical efficacy and bacterial viability data. Aliment Pharmacol. Ther. 42, 1011-1018. doi: 10.1111/ apt.13366

Costello, S. P., Soo, W., Bryant, R. V., Jairath, V., Hart, A. L., and Andrews, J. M. (2017). Systematic review with meta-analysis: fecal microbiota transplantation for the induction of remission for active ulcerative colitis. Aliment Pharmacol. Ther. 46, 213-224. doi: 10.1111/apt.14173

Costello, S. P., Hughes, P. A., Waters, O., and Boryant, R. V. (2019). Effect of Fecal Microbiota Transplantation on 8-Week Remission in Patients With Ulcerative Colitis: A Randomized Clinical Trial. JAMA 321, 156-164. doi: 10.1001/ jama.2018.20046

Cui, B., Feng, Q., Wang, H., Wang, M., Peng, Z., Li, P., et al. (2015). Fecal microbiota transplantation through mid-gut for refractory Crohn's disease: Safety, feasibility, and efficacy trial results J. Gastroenterol. Hepatol. 30, 51-58. doi: 10.1111/jgh.12727

De Jager, C. P., Wever, P. C., Gemen, E. F., Van Oijen, M. G., Van GageldonkLafeber, A. B., Siersema, P. D., et al. (2012). Proton pump inhibitor therapy predisposes to community-acquired Streptococcus pneumoniae pneumonia. Aliment Pharmacol. Ther. 36, 941-949. doi: 10.1111/apt.12069

Drekonja, D., Reich, J., Gezahegn, S., Greer, N., Shaukat, A., Macdonald, R., et al. (2015). Fecal Microbiota Transplantation for Clostridium difficile Infection: A Systematic Review. Ann. Intern Med. 162, 630-638. doi: 10.7326/M14-2693

Erickson, A. R., Cantarel, B. L., Lamendella, R., Darzi, Y., Mongodin, E. F., Pan, C., et al. (2012). Integrated metagenomics/metaproteomics reveals human hostmicrobiota signatures of Crohn's disease. PloS One 7, e49138. doi: 10.1371/ journal.pone.0049138

Fang, H., Fu, L., and Wang, J. (2018). Protocol for Fecal Microbiota Transplantation in Inflammatory Bowel Disease: A Systematic Review and Meta-Analysis. BioMed. Res. Int. 2018, 8941340. doi: 10.1155/2018/8941340
Fischer, M., Kao, D., Kelly, C., Kuchipudi, A., Jafri, S. M., Blumenkehl, M., et al. (2016). Fecal Microbiota Transplantation is Safe and Efficacious for Recurrent or Refractory Clostridium difficile Infection in Patients with Inflammatory Bowel Disease. Inflammation Bowel Dis. 22, 2402-2409. doi: 10.1097/ MIB.0000000000000908

Goyal, A., Yeh, A., Bush, B. R., Firek, B. A., Siebold, L. M., Rogers, M. B., et al. (2018). Safety, Clinical Response, and Microbiome Findings Following Fecal Microbiota Transplant in Children With Inflammatory Bowel Disease. Inflammation Bowel Dis. 24, 410-421. doi: 10.1093/ibd/izx035

Gupta, A., and Khanna, S. (2017). Fecal Microbiota Transplantation. JAMA 318, 102. doi: 10.1001/jama.2017.6466

Gutin, L., Piceno, Y., Fadrosh, D., Lynch, K., Zydek, M., Kassam, Z., et al. (2019). Fecal microbiota transplant for Crohn disease: A study evaluating safety, efficacy, and microbiome profile. U. Eur. Gastroenterol. J. 7, 807-814. doi: 10.1177/2050640619845986

Henson, M. A., and Phalak, P. (2017). Microbiota dysbiosis in inflammatory bowel diseases: in silico investigation of the oxygen hypothesis. BMC Syst. Biol. 11, 145. doi: 10.1186/s12918-017-0522-1

Herfarth, H., Barnes, E. L., Long, M. D., Isaacs, K. L., Leith, T., Silverstein, M., et al. (2019). Combined Endoscopic and Oral Fecal Microbiota Transplantation in Patients with Antibiotic-Dependent Pouchitis: Low Clinical Efficacy due to Low Donor Microbial Engraftment. Inflammation Intest Dis. 4, 1-6. doi: 10.1159/000497042

Kaser, A., Zeissig, S., and Blumberg, R. S. (2010). Inflammatory Bowel Disease. Annu. Rev. Immuno 28, 573-621. doi: 10.1146/annurev-immunol-030409101225

Kelly, C. R., Kahn, S., Kashyap, P., Laine, L., Rubin, D., Atreja, A., et al. (2015). Update on Fecal Microbiota Transplantation 2015: Indications, Methodologies, Mechanisms, and Outlook. Gastroenterology 149, 223-237. doi: 10.1053/ j.gastro.2015.05.008

Kelly, C. R., Khoruts, A., Staley, C., Sadowsky, M. J., Abd, M., Alani, M., et al. (2016). Effect of Fecal Microbiota Transplantation on Recurrence in Multiply Recurrent Clostridium difficile Infection: A Randomized Trial. Ann. Intern Med. 165, 609-616. doi: 10.7326/M16-0271

Khoruts, A., Rank, K. M., Newman, K. M., Viskocil, K., Vaughn, B. P., Hamilton, M. J., et al. (2016). Inflammatory Bowel Disease Affects the Outcome of Fecal Microbiota Transplantation for Recurrent Clostridium difficile Infection. Clin. Gastroenterol. Hepatol. 14, 1433-1438. doi: 10.1016/j.cgh.2016.02.018

Landy, J., Walker, A. W., Li, J. V., Al-Hassi, H. O., Ronde, E., English, N. R., et al. (2015). Variable alterations of the microbiota, without metabolic or immunological change, following fecal microbiota transplantation in patients with chronic pouchitis. Sci. Rep. 5, 12955. doi: 10.1038/srep12955

Levy, A. N., and Allegretti, J. R. (2019). Insights into the role of fecal microbiota transplantation for the treatment of inflammatory bowel disease. Therap. Adv. Gastroenterol. 12, 1756284819836893. doi: 10.1177/1756284819836893

Maharshak, N., Cohen, N. A., Reshef, L., Tulchinsky, H., Gophna, U., and Dotan, I. (2017). Alterations of Enteric Microbiota in Patients with a Normal Ileal Pouch Are Predictive of Pouchitis. J. Crohns. Colitis 11, 314-320. doi: 10.1093/ecco-jcc/jjw157

Moayyedi, P., Surette, M. G., Kim, P. T., Libertucci, J., Wolfe, M., Onischi, C., et al. (2015). Fecal Microbiota Transplantation Induces Remission in Patients With Active Ulcerative Colitis in a Randomized Controlled Trial. Gastroenterology 149, 102-109.e106. doi: 10.1053/j.gastro.2015.04.001

Mullish, B. H., Quraishi, M. N., Segal, J. P., Mccune, V. L., Baxter, M., Marsden, G. L., et al. (2018). The use of fecal microbiota transplant as treatment for recurrent or refractory Clostridium difficile infection and other potential indications: joint British Society of Gastroenterology (BSG) and Healthcare Infection Society (HIS) guidelines. Gut 67, 1920-1941. doi: 10.1136/gutjnl-2018-316818

Natividad, J. M., Pinto-Sanchez, M. I., Galipeau, H. J., Jury, J., Jordana, M., Reinisch, W., et al. (2015). Ecobiotherapy Rich in Firmicutes Decreases Susceptibility to Colitis in a Humanized Gnotobiotic Mouse Model. Inflammation Bowel Dis. 21, 1883-1893. doi: 10.1097/MIB.0000000000000422

Newman, K. M., Rank, K. M., Vaughn, B. P., and Khoruts, A. (2017). Treatment of recurrent Clostridium difficile infection using fecal microbiota transplantation in patients with inflammatory bowel disease. Gut. Microbes 8, 303-309. doi: 10.1080/19490976.2017.1279377

Ni, J., Wu, G. D., Albenberg, L., and Tomov, V. T. (2017). Gut microbiota and IBD: causation or correlation? Nat. Rev. Gastroenterol. Hepatol. 14, 573-584. doi: $10.1038 /$ nrgastro. 2017.88 
Nishida, A., Imaeda, H., Inatomi, O., Bamba, S., Sugimoto, M., and Andoh, A. (2019). The efficacy of fecal microbiota transplantation for patients with chronic pouchitis: A case series. Clin. Case Rep. 7, 782-788. doi: 10.1002/ccr3.2096

Oh, S. R., Ok, S., Jung, T. S., Jeon, S. O., Park, J. M., Jung, J. W., et al. (2017). Protective effect of decursin and decursinol angelate-rich Angelica gigas Nakai extract on dextran sulfate sodium-induced murine ulcerative colitis. Asian Pac. J. Trop. Med. 10, 864-870. doi: 10.1016/j.apjtm.2017.08.017

Paramsothy, S., Kamm, M. A., Kaakoush, N. O., Walsh, A. J., Van Den Bogaerde, J., Samuel, D., et al. (2017a). Multidonor intensive fecal microbiota transplantation for active ulcerative colitis: a randomised placebo-controlled trial. Lancet 389, 1218-1228. doi: 10.1016/S0140-6736(17)30182-4

Paramsothy, S., Paramsothy, R., Rubin, D. T., Kamm, M. A., Kaakoush, N. O., Mitchell, H. M., et al. (2017b). Fecal Microbiota Transplantation for Inflammatory Bowel Disease: A Systematic Review and Meta-analysis. J. Crohns. Colitis 11, 1180-1199. doi: 10.1093/ecco-jcc/jjx063

Persborn, M., Gerritsen, J., Wallon, C., Carlsson, A., and Akkermans, L. M. A. (2013). The effects of probiotics on barrier function and mucosal pouch microbiota during maintenance treatment for severe pouchitis in patients with ulcerative colitis. Aliment Pharmacol. Ther. 38, 772-783. doi: 10.1111/apt.12451

Quraishi, M. N., Widlak, M., Bhala, N., Moore, D., Price, M., Sharma, N., et al. (2017). Systematic review with meta-analysis: the efficacy of fecal microbiota transplantation for the treatment of recurrent and refractory Clostridium difficile infection. Aliment Pharmacol. Ther. 46, 479-493. doi: 10.1111/apt.14201

Rodemann, J. F., Dubberke, E. R., Reske, K. A., Seo, D. H., and Stone, C. D. (2007). Incidence of Clostridium difficile infection in inflammatory bowel disease. Clin. Gastroenterol. Hepatol. 5, 339-344. doi: 10.1016/j.cgh.2006.12.027

Rossen, N. G., Fuentes, S., Van Der Spek, M. J., Tijssen, J. G., Hartman, J. H. A., Duflou, A., et al. (2015). Findings From a Randomized Controlled Trial of Fecal Transplantation for Patients With Ulcerative Colitis. Gastroenterology 149, 110-118.e114. doi: 10.1053/j.gastro.2015.03.045

Rubin, D. T. (2015). Fecal Microbiota Transplantation for the Treatment of Inflammatory Bowel Disease. Gastroenterol. Hepatol. (N. Y.) 11, 618-620.

Selvig, D., Piceno, Y., Terdiman, J., Zydek, M., Umetsu, S. E., Balitzer, D., et al. (2020). Fecal Microbiota Transplantation in Pouchitis: Clinical, Endoscopic, Histologic, and Microbiota Results from a Pilot Study. Dig. Dis. Sci. 65 (4), 1099-1106. doi: 10.1007/s10620-019-05715-2

Sheehan, D., Moran, C., and Shanahan, F. (2015). The microbiota in inflammatory bowel disease. J. Gastroenterol. 50, 495-507. doi: 10.1007/s00535-015-1064-1

Shen, B. (2012). Bacteriology in the etiopathogenesis of pouchitis. Dig. Dis. 30, 351-357. doi: 10.1159/000338125

Sokol, H., Pigneur, B., Watterlot, L., Lakhdari, O., Bermúdez-Humarán, L. G., Gratadoux, J. J., et al. (2008). Fecalibacterium prausnitzii is an antiinflammatory commensal bacterium identified by gut microbiota analysis of Crohn disease patients. Proc. Natl. Acad. Sci. U.S.A. 105, 16731-16736. doi: 10.1073/pnas.0804812105

Sokol, H., Landman, C., Seksik, P., Berard, L., Montil, M., Nion-Larmurier, I., et al. (2020). Fecal microbiota transplantation to maintain remission in Crohn's disease: a pilot randomized controlled study. Microbiome 812 (1). doi: 10.1186/ s40168-020-0792-5

Sood, A., Mahajan, R., Singh, A., Midha, V., Mehta, V., Narang, V., et al. (2019). Role of Faecal Microbiota Transplantation for Maintenance of Remission in Patients With Ulcerative Colitis: A Pilot Study. J. Crohns. Colitis 13, 13111317. doi: 10.1093/ecco-jcc/jjz060

Sood, A., Singh, A., Mahajan, R., Midha, V., Mehta, V., Gupta, Y. K., et al. (2020). Acceptability, tolerability, and safety of fecal microbiota transplantation in patients with active ulcerative colitis (AT\&S Study). J. Gastroenterol. Hepatol. 35, 418-424. doi: 10.1111/jgh.14829
Stallmach, A., Lange, K., Buening, J., Sina, C., Vital, M., and Pieper, D. H. (2016). Fecal Microbiota Transfer in Patients With Chronic Antibiotic-Refractory Pouchitis. Am. J. Gastroenterol. 111, 441-443. doi: 10.1038/ajg.2015.436

Surawicz, C. M., Brandt, L. J., Binion, D. G., Ananthakrishnan, A. N., Curry, S. R., Gilligan, P. H., et al. (2013). Guidelines for diagnosis, treatment, and prevention of Clostridium difficile infections. Am. J. Gastroenterol. 108, 478498. doi: 10.1038/ajg.2013.4

Suskind, D. L., Brittnacher, M. J., Wahbeh, G., Shaffer, M. L., Hayden, H. S., Qin, X., et al. (2015). Fecal Microbial Transplant Effect on Clinical Outcomes and Fecal Microbiome in Active Crohn's Disease. Gastroenterol. Hepatol. (N. Y.) 21, 556-563. doi: 10.1097/MIB.0000000000000307

Terveer, E. M., Van Beurden, Y. H., Goorhuis, A., Seegers, J., Bauer, M. P., Van Nood, E., et al. (2017). How to: Establish and run a stool bank. Clin. Microbiol. Infect. 23, 924-930. doi: 10.1016/j.cmi.2017.05.015

Vaughn, B. P., Vatanen, T., Allegretti, J. R., Bai, A., Xavier, R. J., Korzenik, J., et al. (2016). Increased Intestinal Microbial Diversity Following Fecal Microbiota Transplant for Active Crohn's Disease. Inflamm. Bowel Dis. 22, 2182-2190. doi: 10.1097/MIB.0000000000000893

Vermeire, S., Joossens, M., Verbeke, K., Wang, J., Machiels, K., Sabino, J., et al. (2016). Donor Species Richness Determines Fecal Microbiota Transplantation Success in Inflammatory Bowel Disease. J. Crohns. Colitis 10, 387-394. doi: 10.1093/ecco-jcc/jjv203

Wang, Y., Ren, R., Sun, G., Peng, L., Tian, Y., and Yang, Y. (2020). Pilot study of cytokine changes evaluation after fecal microbiota transplantation in patients with ulcerative colitis. Int. Immunopharmacol. 85, 106661. doi: 10.1016/ j.intimp.2020.106661

Wei, Y., Zhu, W., Gong, J., Guo, D., Gu, L., Li, N., et al. (2015). Fecal Microbiota Transplantation Improves the Quality of Life in Patients with Inflammatory Bowel Disease. Gastroenterol. Res. Pract. 2015, 517597. doi: 10.1155/2015/517597

Wei, Y. L., Chen, Y. Q., Gong, H., Li, N., Wu, K. Q., Hu, W., et al. (2018). Fecal Microbiota Transplantation Ameliorates Experimentally Induced Colitis in Mice by Upregulating AhR. Front. Microbiol. 9, 1921. doi: 10.3389/fmicb.2018.01921

White, C., Thakor, A., and Goel, R. (2018). Recommended drug therapies for inflammatory bowel disease. Prescriber 29, 17-22. doi: 10.1002/psb.1701

Xiang, L., Ding, X., Li, Q., Wu, X., Dai, M., Long, C., et al. (2020). Efficacy of faecal microbiota transplantation in Crohn's disease: a new target treatment? Microb. Biotechnol. 13, 760-769. doi: 10.1111/1751-7915.13536

Zeng, W., Shen, J., Bo, T., Peng, L., Xu, H., Nasser, M.II, et al. (2019). Cutting Edge: Probiotics and Fecal Microbiota Transplantation in Immunomodulation. J. Immunol. Res. 2019, 1603758. doi: 10.1155/2019/1603758

Zhou, M., He, J., Shen, Y., Zhang, C., Wang, J., and Chen, Y. (2017). New Frontiers in Genetics, Gut Microbiota, and Immunity: A Rosetta Stone for the Pathogenesis of Inflammatory Bowel Disease. BioMed. Res. Int. 2017, 8201672. doi: $10.1155 / 2017 / 8201672$

Zuo, T., and Ng, S. C. (2018). The Gut Microbiota in the Pathogenesis and Therapeutics of Inflammatory Bowel Disease. Front. Microbiol. 9:2247. doi: 10.3389/fmicb.2018.02247

Conflict of Interest: The authors declare that the research was conducted in the absence of any commercial or financial relationships that could be construed as a potential conflict of interest.

Copyright (C) 2020 Tan, Li, Shen and Feng. This is an open-access article distributed under the terms of the Creative Commons Attribution License (CC BY). The use, distribution or reproduction in other forums is permitted, provided the original author(s) and the copyright owner(s) are credited and that the original publication in this journal is cited, in accordance with accepted academic practice. No use, distribution or reproduction is permitted which does not comply with these terms. 